ANNALS, $A A P S S$, 473, May 1984

\title{
Collective Bargaining: The Next Twenty Years
}

\author{
By DORIS B. McLAUGHLIN \\ in consultation with \\ DOUGLAS A. FRASER
}

\begin{abstract}
Collective bargaining will evolve in the next 20 years in response to the changes taking place in the world of work and union reaction to those changes. Job security will be a central issue, with increased emphasis on reducing work time to create more jobs. We also foresee more union mergers and increased inclusion in the labor movement of workers not traditionally a part of the union's constituency. That, in turn, will further erode the effectiveness of centralized bargaining. Moreover, unions will attempt to alter their traditional role as reactors to managements' unilateral actions and see themselves as partners with management. The role of the government and the courts may alter the collective bargaining process, but whether it will erode or strengthen that process is still an open question.
\end{abstract}

Doris B. McLaughlin is an associate research scientist at the Institute of Labor and Industrial Relations, University of Michigan. Her major work has been in labor history and collective bargaining, with a recent emphasis on technology's impact on jobs.

Douglas A. Fraser, former president of the United Automobile Workers union, remains very prominent in labor-management relations. A member of Chrysler's board of directors and of a U.S.-Japan trade commission, he teaches at Wayne State University and Harvard University and lectures throughout the United States. 
T OW will the collective bargaining 1 process in this country be influenced by the changes that are occurring in the world of work? Before addressing that question, we will first outline what those changes are. Then, because unions play a vital role in the collective bargaining process, we will describe how they are coping with those changes. Finally, we will consider the original question posed.

\section{THE CHANGING WORLD OF WORK}

"Robots." "Satellites." "Microelectronics." "Computer-aided design." "Computer-aided manufacturing." Words and phrases traditionally associated with the world of science fiction have recently become part of the real world of work. Their entry has changed the way work is done; how long it takes to do it; where it is performed; and who or what does it.

Because those science fiction concepts are now a reality, this country has become an integral part of a global economy. Both here and abroad we are now in competition with other technologically oriented industrial nations to produce and sell manufactured goods. To a lesser extent, we are also competing with less developed countries to provide basic services long distance. We often enter those contests at a disadvantage, partially due to the strong dollar. Jobs are lost to the American worker when a U.S. firm transfers some of its operations to another country in order to compete more effectively in foreign markets. The well-publicized shortcomings of basic U.S. education compared to the educational systems of our industrial competitors merely compound the problem.
These disadvantages have acclerated a shift in our economy beginning after World War II, from one that was primarily product-oriented to one that is increasingly service-oriented. By 1960 , jobs in the service sector amounted to 62 percent of total nonagricultural employment. By 1981 the figure had risen to 72 percent. Despite growing foreign competition in the service sector, some jobs cannot be provided long distance-those provided by janitors, nurses' aides, cashiers, repairmen, barbers, and the like. Moreover, this nation still leads in developing the more sophistcated, often highly technical, computerized systems to gather, analyze, and disseminate information-services for which there is a growing demand worldwide. That leading position, too, helps to account for the dominance of the service sector in this country.

While those intriguing service areas have created some new jobs, they have not created enough to offset the jobs lost in manufacturing and basic services. Moreover, those displaced from the more traditional jobs, as well as those seeking to enter the labor market for the first time, are often not trained to step into the new jobs that are becoming available. Thus many labor market forecasters are predicting that we will become a two-tiered society. The upper tier, consisting of those skilled in the new requirements of the world of work, will be highly paid and in short supply. The members of the lower tier, in contrast, lacking the requisite skills, will be low-wage workers and a glut on the labor market. Indeed, in his article on "The Declining Middle," Bob Kuttner conjectured that "the country's future as a middle-class society is in jeopardy."1

1. Atlantic Monthly, p. 60 (July 1983). 


\section{UNION RESPONSE}

Labor unions in this country, many adversely affected by the unemployment resulting from the changing nature of work, are trying to cope with the challenge by negotiating contract language that affords at least partial protection to their adversely affected members. Such language includes clauses such as those assuring rate retention for those employed when the contract is signed, transfer rights, advance notice of plant closings and/or the introduction of new technology, severance pay, early retirement benefits, work-force reduction by attrition only, and retraining rights. Some clauses covering retraining rights call for those rights to be on a continuing basis, in order to deal with new technological advances whenever they are introduced.

Less common clauses include one negotiated by the telegraphers that provides for a larger lump sum in severance pay for members with lesser rather than greater seniority, in order to preserve the jobs that remain for the older worker who might have more difficulty in finding alternate employment than would a younger counterpart. Another interesting clause is that negotiated by the Communication Workers of America, which established a jointly funded program to train members in a cluster of skills, thus making them more readily employable should their current jobs be phased out.

Another interesting example-this time achieved by means of a letter of agreement - is the three-pronged retraining and career counseling program jointly administered by the United Automobile Workers (UAW) and the Ford Motor Company. It consists of two types of retraining programs designed for UAW members on layoff from Ford. One is a prepaid tuition-assistance plan under which qualified persons can pursue an educational program of their choice to improve their chances of reemployment either at Ford or elsewhere. The second consists of job-specific retraining in a skill, in cases in which definite job prospects have been identified. The career counseling program is designed to assist Ford workers still on the job in formulating their personal and career goals.

Some unions-in the automobile, steel, and trucking and rubber industries, for example-have agreed to make contractual concessions in the way of wage reductions or freezes, changes in work rules, the elimination of adjustments in the cost-of-living allowance, and the like.

Such concessions are made only if the unions involved are convinced that the employer is in financial distress and requires those cutbacks to remain viable. Typically, as Thomas A. Kochan and Harry $\mathrm{C}$. Katz have pointed out, the employers asking for concessions are in industries in which

demand for product [had declined] in a business cycle or [has tapered] off during the mature stages of a product life cycle, [where] competitive pressures on a firm lead employers to tighten work practices as the importance of meeting production schedules and achieving high volumes of output decline relative to the importance of controlling costs.

During these periods, excess capacity in the industry is likely to develop, placing highcost producers at a severe competitive disadvantage in the marketplace. All of this suggests that the intensity of management efforts to change work rules will vary inversely with 
the business cycle and directly with the age in the life cycle of the product or industry. ${ }^{2}$

Some requested concessions, however, are rarely agreed to, despite an employer's unfavorable competitive position. For example, in recent years many employers, alarmed at the escalating health-care costs, have sought to have their workers bear part of the expense of their own medical bills. Boeing sought insurance deductibles from the Machinists Union, and American Telephone and Telegraph proposed that its telephone workers pay 20 percent of their medical expenses. Both requests, and similar ones made by other employers of unions they bargain with, were flatly rejected. Attempts to cut back the number of holidays or the length of vacations have also not fared well.

When unions do make concessions, they also attempt to obtain some quid pro quo-for instance, enhanced job security, a greater voice in decision making, more complete disclosure by the employers of their financial position, or profit sharing, to have funds set aside for training programs, to prohibit plant closings, to prevent obtaining materials and thus labor from outside the plants, and/or to provide income guarantees if high-seniority members are laid off. In so doing, they are trading what they believe to be a temporary setback for what they hope will be a permanent gain.

Because foreign competition adversely affects both employee and employer,

2. "Collective Bargaining, Work Organization, and Worker Participation: The Return to Plant-Level Bargaining," in Proceedings of the 1983 Spring Meeting of the Industrial Relations Research Association (Madison, WI: IRRA, 1983), p. 526. a number of unions have joined with the employers with whom they bargain to try to find ways of improving their competitive position by increasing both productivity and product quality. In some instances this has entailed the creation of informal labor-management committees whose members meet periodically to discuss topics ranging from ways to improve product quality and productivity to the solution of worker health and safety problems and finding the most efficient way to implement technological change. In other instances more formal employee-involvement programs have been established, but the goals are the same. However agreed to, if successfully implemented, the end result is greater worker and union participation in the decision-making process.

In the past three decades, for a variety of reasons-foreign competition, the introduction of labor-saving devices, and the movement from the Snowbelt to the Sunbelt among them-the percentage of union members in the labor force has been dropping steadily. To try to recolip their losses, the AFL-CIO, as well as individual unions, have renewed their efforts to organize the unorganized. To do so, many of the unions are reaching out to people working in jobs not usually associated with traditional union jurisdictions. As a result, a number of unions have an increasingly diversified membership, with a variety of concerns and demands. The United Food and Commercial Workers, for example, represent not just retail clerks and meat cutters but barbers, racetrack tellers, and insurance salesmen as well. As a consequence, centralized bargaining, once so effective, is becoming less so, and is giving way to a more decentralized approach. 
In additicn, again in the face of dwindling membership, weaker unions are often merging with stronger ones. The printing industry unions are a prime example. For the weaker union, the merged organization has the advantage of redressing the balance of power between labor and management, as well as revitalizing the ability to serve its members more effectively. For the stronger union, the gain is seen in terms of additional members and other resources that the smaller organization brings. Again, however, the more diverse membership requires a more decentralized approach to collective bargaining.

Some unions are also broadening the scope of their mission. For example, in some parts of the country the UAW has established job-referral and assistance centers to help not just unemployed auto workers but any unemployed worker in that given geographic region. The primary function of those centers is to direct the unemployed to the various governmental agencies that can offer them help in some way. Charles $M$. Rehmus points out another example:

to a surprising extent, labor lobbies in areas which are not of direct concern to union members. For example, labor is perhaps the largest organization supporting civil rights legislation in the United States. ${ }^{3}$

Because we now operate in a global economy, unions have taken a few steps, albeit hesitant ones, in the direction of internationalizing the labor movement. They, along with their foreign counterparts, are beginning to feel the need to take wage rates out of competition and

3. "Labor and Politics in the 1980s," this issue of The Annals of the American Academy of Political and Social Science. regularize the worldwide market. Thus we are seeing some international trade union confederations becoming more active, and that trend - though spottyshould continue.

Unions, then, are using a variety of means to try to cope with the changing world of work-by negotiating protective contract language, by opening the door to gain a greater voice in decision making, by combining with one another, by broadening the role they play as spokespersons for the American workers, and by trying to work more closely with their foreign counterparts.

While some of their attempts may not meet with immediate success-internationalization of the labor movement is almost certain to run into formidable obstacles, for example-other efforts will have a permanent effect on labormanagement relations in this country and, thus, an impact on the collective bargaining process itself.

\section{THE IMPACT ON COLLECTIVE BARGAINING}

Now to our opening question, How will the collective bargaining process in this country be influenced by the changes that are occurring in the world of work? Some observers believe that even when the economy recovers, the traditional adversarial relationship between management and labor will continue to give way to a spirit of cooperation, or, as Daniel B. Mitchell puts it, "that Humpty Dumpty ... [has] fallen off the wall and never will be put together again." At the other end of the spectrum are those who contend that, once the recession is finally over, the parties will abandon the concept of cooperation and revert to the past, that "Humpty falls off the wall 
from time to time, but has not broken in the past and has always climbed back."

Our own view is somewhere in the middle. True, Humpty does always climb back. But every time he does, the wall he then sits on is lower to the ground than the one before. In other words, the process has historically been one of two steps forward, one step back, and will, as far as we can see. follow the same set of steps over the next two decades. There will be evolution - but no revolution.

What more specific changes do we foresee?

1. A trend already evident is the unions' increased emphasis on job security for their members still at work. To increase job opportunities for those who are unemployed, unions have begun to push for reduced work time. As productivity increases with the introduction of further technological advances and requires even less labor, the push for such things as a shorter work day, reduced workweek, longer vacations, more holidays, paid absence allowances, and a tightening of overtime restrictions will become more and more common. The unions' demands for paid educational leave for their members will also increase, not just to create more jobs but also as a means of preparing their members for future technological changes.

2. More union mergers and increased inclusion of workers who have not been a part of the unions' traditional constituency will continue to erode the effectiveness of centralized bargaining; decen-

4. "Is Union Wage Determination at a Turning Point?" in Proceedings of the Thirty-fifth Annual Meeting of the Industrial Relations Research Association (Madison, WI: IRRA, 1983), p. 360 . tralized bargaining will become the primary and most effective mode.

3. More and more, unions and their members will attempt to alter their traditional role as reactors to management's unilateral actions. They are seeing themselves as partners-very independent ones, but partners neverthelessin a joint effort to keep the enterprise afloat. Whether because union members are now stockholders, share in profits, or have at least been given information hitherto unavailable to them, they know more, care more, and can act more effectively.

4. An item purposely slighted until now is the role of government and the courts with respect to Iabor-management relations. The increase in government regulation and in litigation brought to redress perceived individual wrongs that are covered under existing laws also has an effect on the collective bargaining process. It has become increasingly legalized and has broadened the kinds of issues the parties bring to the bargaining table. Whether this will eventually erode or strengthen the collective bargaining process is still an open question.

To give one example, the commonlaw doctrine of employment at will-the concept that an employer has the right to employ and/or discharge a person whenever the employer unilaterally decides to-has been eroded considerably by the courts. Nonunion workers who earlier were denied the rights that union members had through the grievance procedure have now successfully challenged cases of preferential hiring and/ or arbitrary discharge through litigation. With redress to the courts some workers may come to feel that they no longer need a union to defend their 
interests. On the other hand, given the amount of time and money involved in an individual challenge compared to filing a grievance through a union, workers may well feel that joining a union is the better route to take.

Another example is employers who have filed for protection from creditors and the terms of costly labor contracts under bankruptcy laws. Union leaders have appealed both to Congress and the courts to bar that means of avoiding contractual commitments. At this writing Congress has not acted, but the Supreme Court has heard oral arguments in one such case. What the Court decides will have a decided impact on the future of collective bargaining. 